\title{
Operations of the Federal Reserve Bank of St. Louis-1969
}

T is one of twelve banks which, along with the Board of Governors in Washington, D. C., make up the Federal Reserve System. The St. Louis Bank's geographic responsibility, the Eighth Federal Reserve District, includes Arkansas and portions of Illinois, Indiana, Kentucky, Mississippi, Missouri, and Tennessee. Branches in Little Rock, Louisville, and Memphis aid the St. Louis bank in its operations.

The operations of each Federal Reserve Bank can be divided into three major classes. First, it provides a variety of services for commercial banks (mainly member banks), the Federal Government, and the public. Second, it supervises certain banks in the Eighth District. Third, it aids in the formulation of national monetary policy. This report of the past year's operations discusses these three areas and related functions.

\section{Service Operations}

Each Federal Reserve Bank provides five major service operations: lending money to member banks; furnishing currency and coin for circulation; maintaining facilities for the collection and clearing of checks; maintaining the legal reserve accounts of

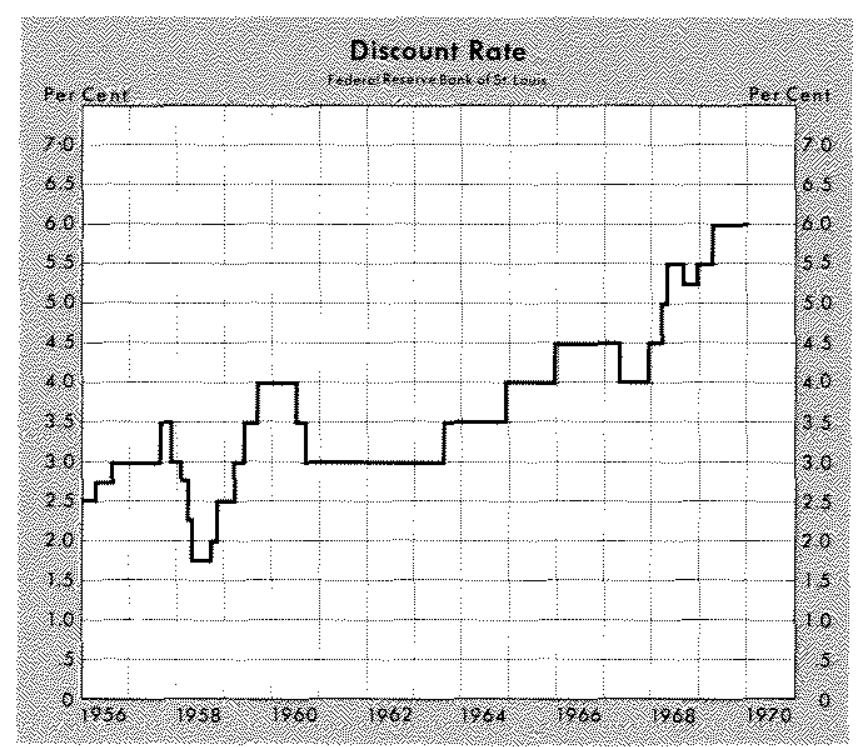

member banks; and acting as a fiscal agent of the U. S. Treasury. The volume of most service operations at this bank's four offices increased in 1969 , reflecting growth in economic activity in the Central Mississippi Valley. The increased volume of operations is reflected by an increase in employment in this bank's four offices from 1,193 on January 1, 1969 to 1,289 on January 1,1970 , an increase of 8 per cent.

\section{Lending}

Federal Reserve Banks are "bankers' banks." For example, under certain circumstances, com. mercial banks borrow from the Reserve Banks in much the same way that individuals and corporations borrow from their banks. This is done through advances and discounting. Although advances are the usual means by which credit is extended, a custom has developed of calling these loans discounts and the interest charged the discount rate. Lending through this mechanism is initiated by the borrowing bank, but the frequency and amount of borrowing by any one member bank is limited by the Federal Reserve Banks.

Daily borrowing from the St. Louis Federal Reserve Bank averaged $\$ 42$ million in 1969 , compared with $\$ 17$ million in 1968, $\$ 6$ million in 1967 , and $\$ 32$ million in 1966. In 1969, 22 per cent of the member

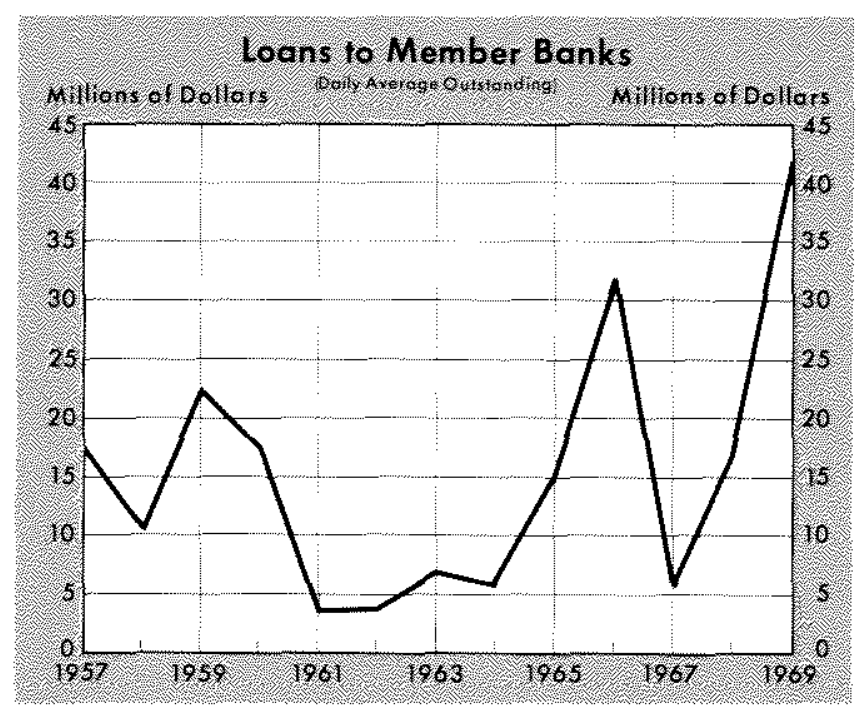




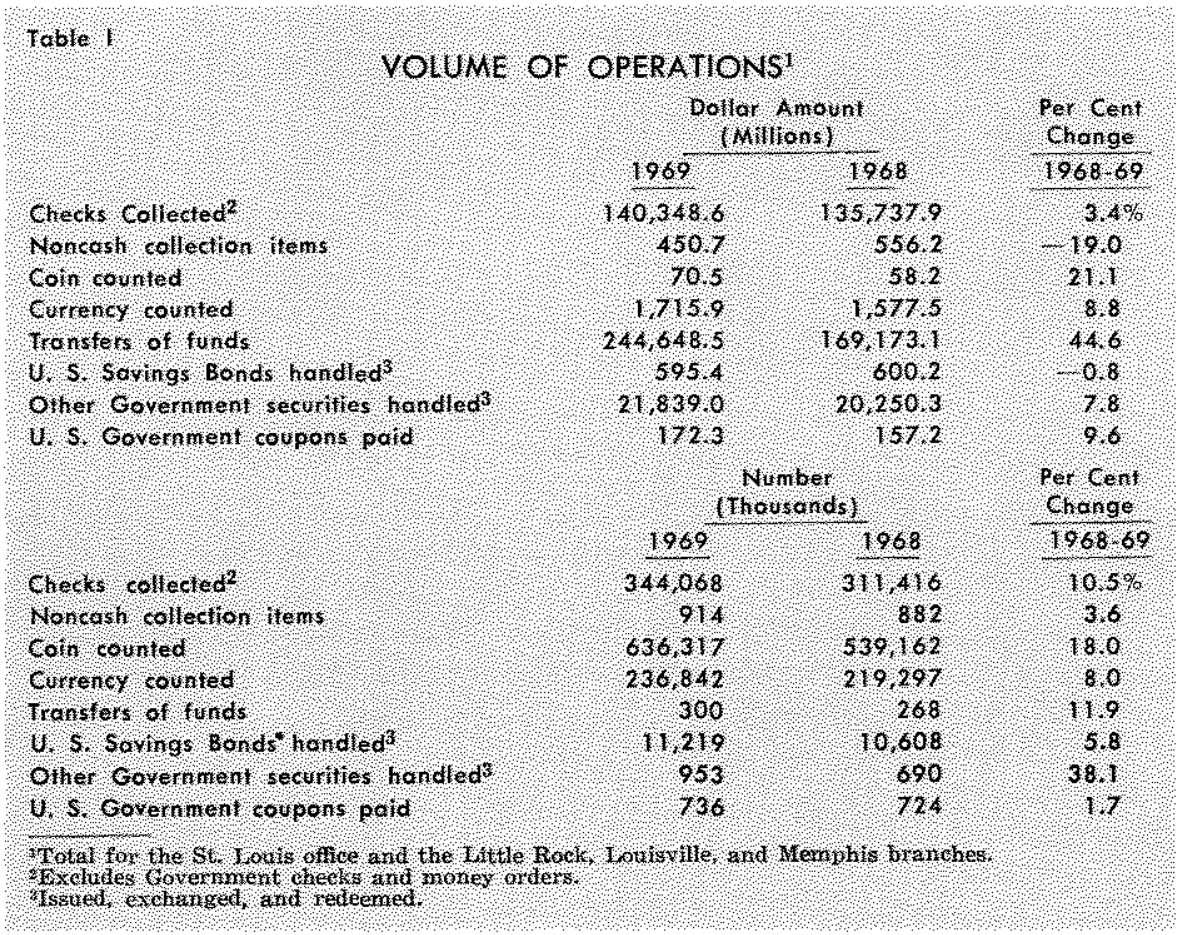

In 1969, coin handling continued the sharp rise of the past several years, demonstrating further recovery from the severe coin shortage which occurred in the mid-1960's. The demand for coins nationally has been fed in part by the inflation of recent years, and there has probably been some positive influence from the increasing use of coin-operated vending machines. The number of pieces counted at the Bank rose from 227 million in 1964 to 636 million in 1969 , an average annual increase of 23 per cent. Meanwhile, the dollar value increased from $\$ 25$ million to $\$ 71$ million.

A total of 237 million pieces of currency was handled in 1969,8 per cent above the previous year. The dollar value of currency han-

banks in the district borrowed from the Federal Re. serve, compared with 13 per cent in 1968. While market interest rates rose rapidly in 1969 , the discount rate was raised only once - on April 4, from $51 / 2$ to 6 per cent. ${ }^{1}$ Incentive to borrow from the Federal Reserve was increased with the enlarged spread between the market rate and the discount rate.

\section{Coin and Currency Operations}

Just as businesses and individuals obtain coin and currency from commercial banks, commercial banks obtain them at Federal Reserve Banks. Member banks withdraw directly from the Federal Reserve Bank, while nonmember banks withdraw from member banks or with permission from the accounts of member banks at the Federal Reserve Bank. When banks receive an excess of coin and currency from their customers, it is deposited with the Federal Reserve Bank. There it is sorted and counted, the usable money is held for redistribution, and the nonusable money is destroyed.

1 Under present law, when a member bank borrows from its Reserve Bank on collateral that does not meet certain "eligibility" requirements, it must pay interest at a rate one half of 1 per cent higher than the Reserve Bank's nomal discount rate. The Board of Governors has recommended leg. islation that would permit a member bank, in appropriate cir. cumstances, to borrow on any collateral satisfactory to its Reserve Bank, without the necessity of paying a "penalty" rate of one-half of 1 per cent. dled amounted to $\$ 1.7$ billion, an increase of 9 per cent from a year earlier. The increase in currency probably reflects the increase in personal income and the related rise in transactions, along with the increase in the price level.

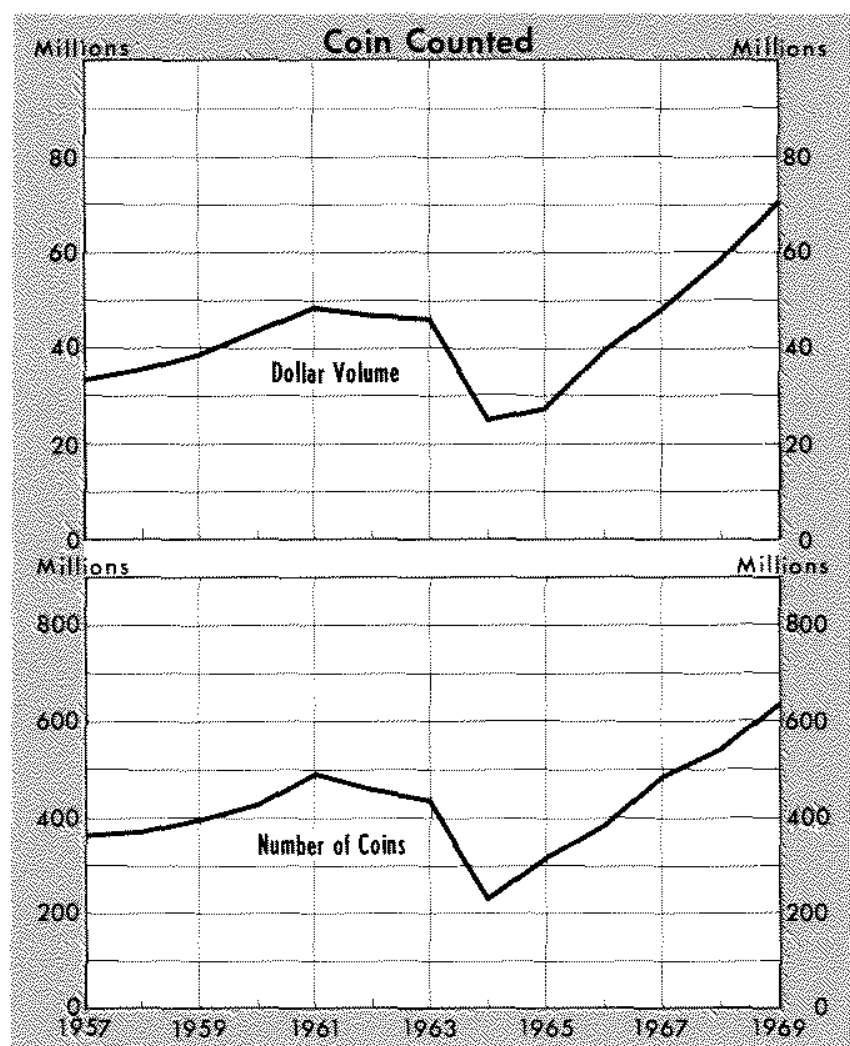




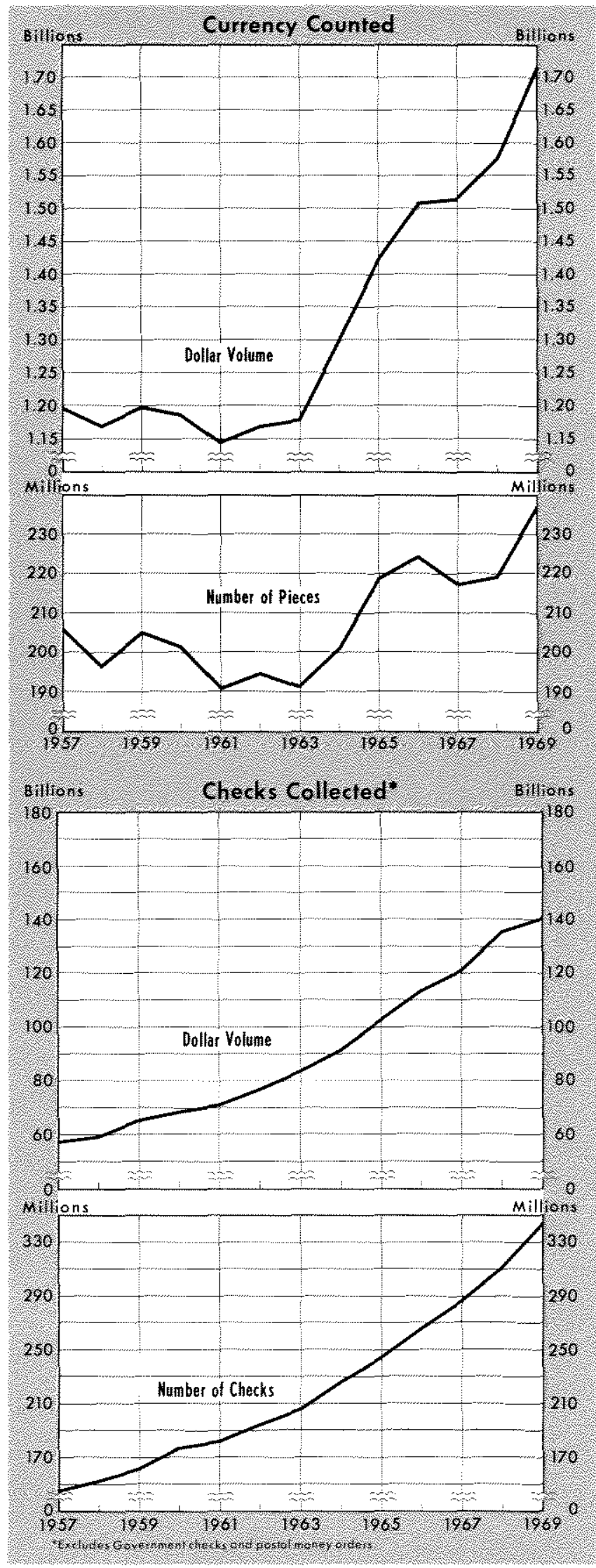

\section{Check Clearing}

Federal Reserve Banks participate in collecting checks and provide a mechanism through which commercial banks settle for checks collected. The four offices of this bank receive checks from district member banks, other Federal Reserve Banks, and Government agencies for collection. A Federal Reserve Bank also sometimes receives checks directly from member banks in other Districts to increase the speed of collections. Checks received are drawn either on banks in the Eighth District which remit at par, par remitting banks in other districts, or the United States Treasury. The dollar volume of checks collected rose from $\$ 136$ million in 1968 to $\$ 140$ million in 1969, an increase of 3.4 per cent. The number of checks collected rose from 311 million in 1968 to 344 million in 1969 , an increase of 10.5 per cent. The number of checks collected in all of the banks in the Federal Reserve System increased 10 per cent from 1968 to 1969 . The fact that the number of checks collected has increased more rapidly than the dollar amount probably indicates that more people are using checks for purchasing. Two possible reasons for the

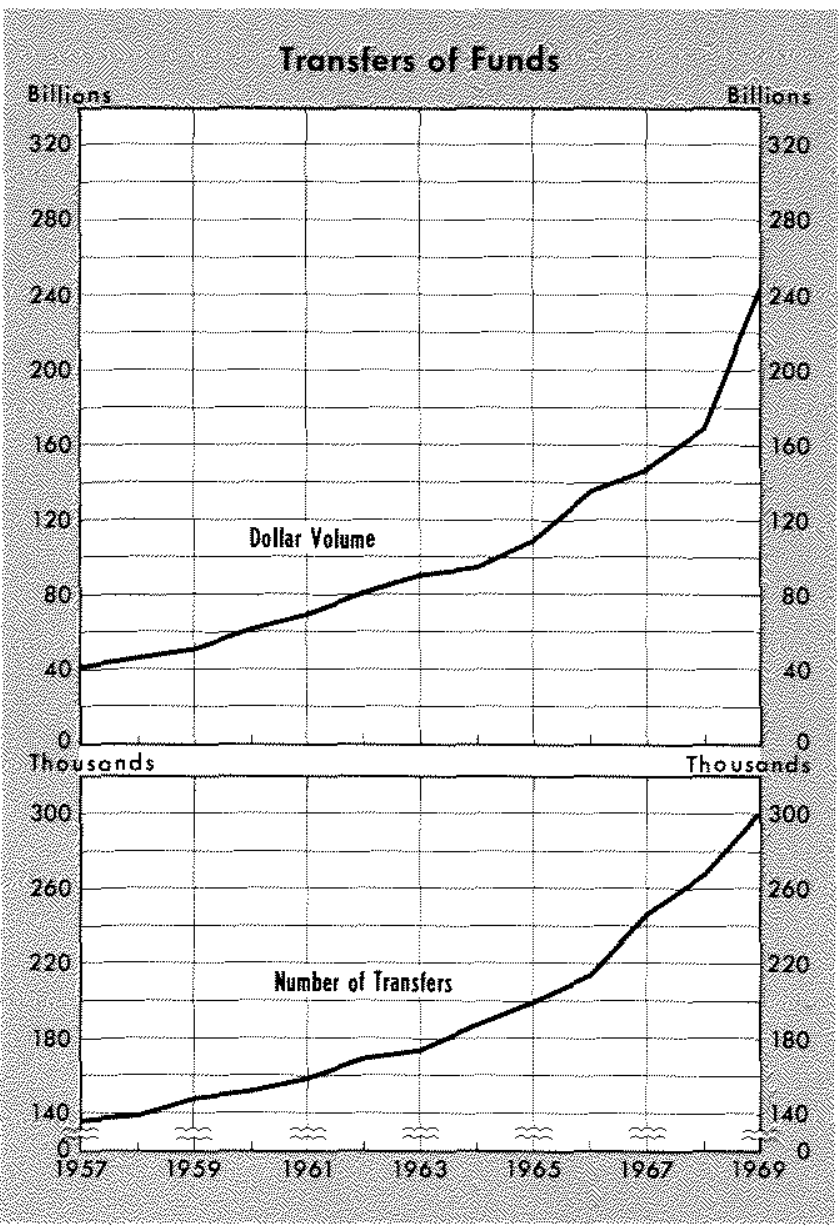

Page 12 
increased popularity of paying by check are that many banks have eliminated or lowered service charges on demand deposits.

\section{Transfers of Tunds}

Wire transfers of funds are largely movements of member bank balances among Federal Reserve Banks. Such transfers result primarily from transactions in the Federal Funds market, check collection settlements, and transfers in connection with U. S. Treasury obligations. The number and dollar value of such transfers have risen sharply in recent years. This Bank was party to 300 thousand transfers in 1969,12 per cent above the 268 thousand transfers in $: 968$. Dollar value was $\$ 245$ billion, up 45 per cent over 1968.

\section{Fiscal Agency Operations}

Each Federal Reserve Bank acts as a depository and fiscal agent of the United States Treasury. In this capacity the Federal Reserve Banks carry the principal checking accounts of the Treasury, issue and

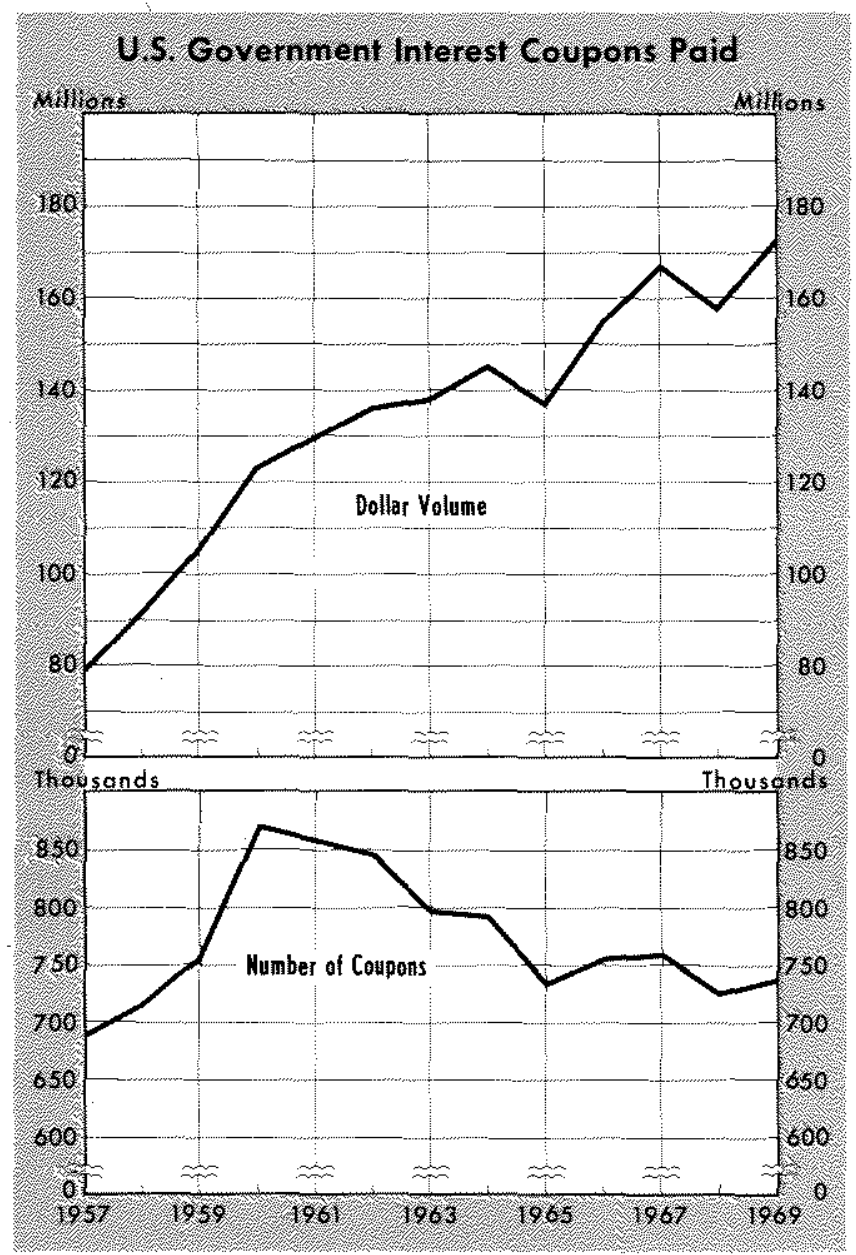

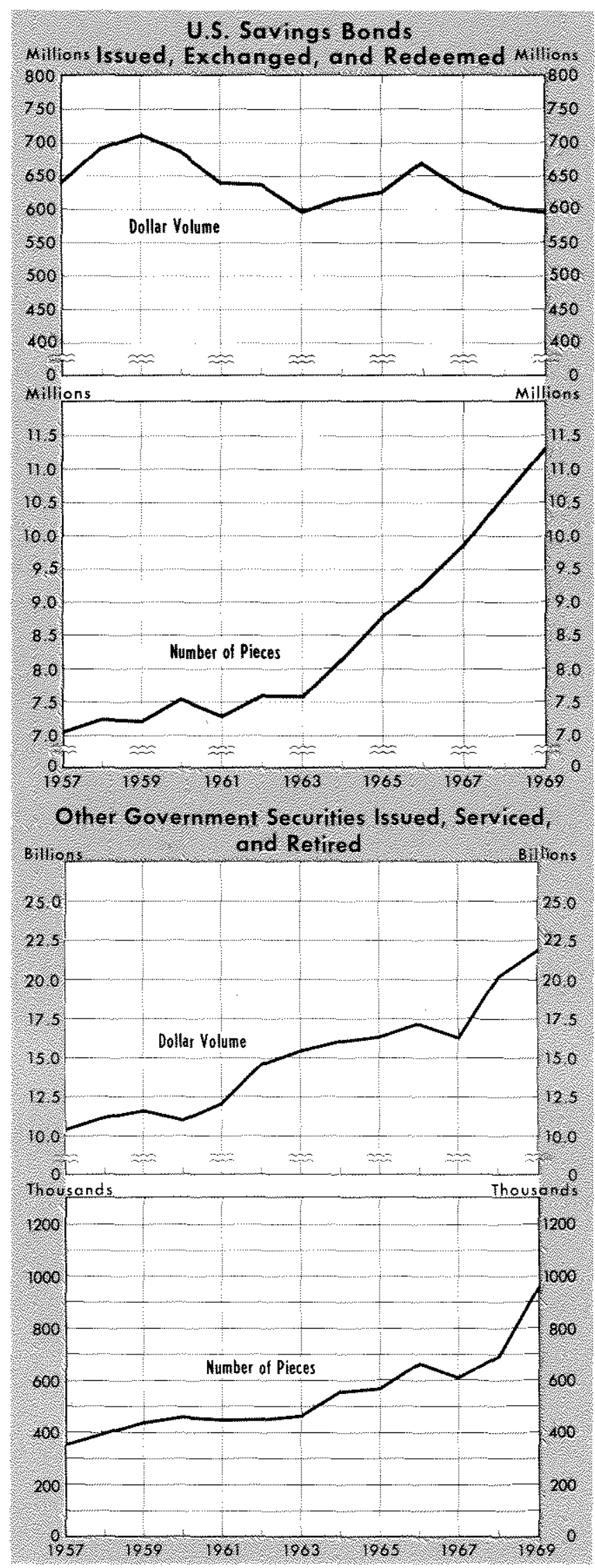

Page 13 
redeem Government securities, administer the Treasury tax and loan accounts with commercial banks, and perform various other Government financial duties.

The four offices of this bank in 1969 issued, exchanged, and redeemed 11 million U. S. Savings Bonds valued at $\$ 595$ million. The number of bonds handled rose 6 per cent from 1968, while the dollar value declined 1 per cent. Other government securities issued, serviced, and retired totaled 953 thousand, 38 per cent above a year earlier, while dollar value was up 8 per cent to $\$ 22$ billion.

\section{Supervision and Examination}

The Federal Reserve System, along with state authorities, exercise supervision over state-chartered banks which are members of the Federal Reserve System, with the objective of fostering and maintaining a sound banking system. Supervision includes annual examinations which provide the information for evaluation of the assets, operations, policies, and management of the banks subject to review. This enables the supervisory authorities to help prevent or correct situations that might adversely affect the soundness of the banks, and the public interest. All state member banks in the district were examined in 1969. ${ }^{2}$

Other supervisory functions of the Federal Reserve System include admission of state banks to membership in the System, approval for the establishment of domestic and foreign branches, approval for merger or absorption of other banks by state member banks, and permission to establish registered bank holding companies and for such companies to acquire stock in banks. Much of the investigation involved in these supervisory functions is conducted by the Federal Reserve Banks.

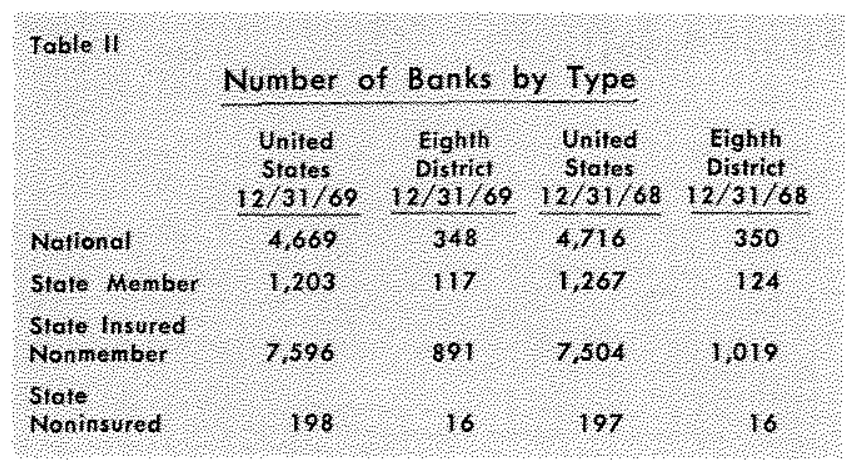

2 Four agencies have the authority to supervise private commercial banks. The Comptroller of the Currency's major supervisory responsibility is National Banks; the Federal Reserve, for the most part, examines state member banks; the Federal Deposit Insurance Corporation mainly supervises state insured nonmember banks; and the state supervisory authorities examines all state banks (including both insured and noninsured).

\section{Research}

The research staff of the bank performs two major roles. One is to analyze national and regional financial situations with a view to formulation of monetary policy recommendations. These recommendations are used by the President of the Bank in the deliberations of the Federal Open Market Committee.

The second function of the research staff is to provide economic information to the public, principally through the monthly Review and other recurring releases. The research staff also provides data and analyses which facilitate other operations of the System; for instance, research into the structure of banking markets aids in determining the advisability of mergers and holding company applications.

\section{Statements}

Total assets of the Federal Reserve Bank of St. Louis were $\$ 3.2$ billion on December 13,1969 , an increase of 9 per cent from a year earlier. Most of the rise in assets was due to increased holdings of U. S. Government securities, which resulted from the operations of the System Open Market Account. These open market operations, which are the major instrument of monetary policy, are authorized by the Federal Open Market Committee and are undertaken at the Federal Reserve Bank of New York by the

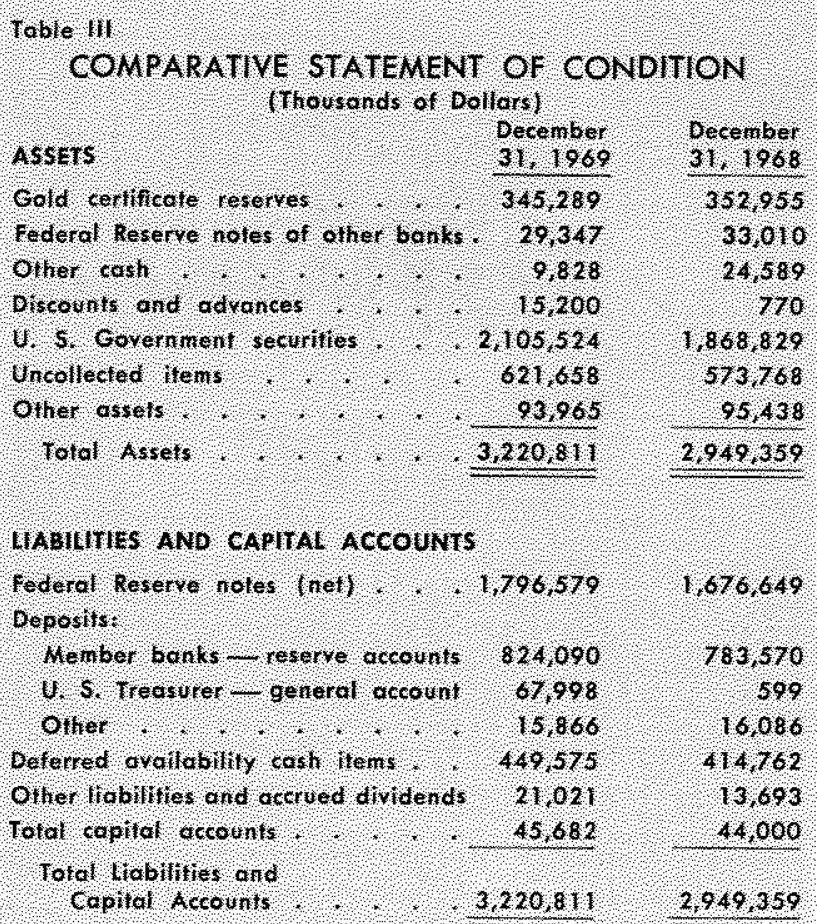

Page 14 


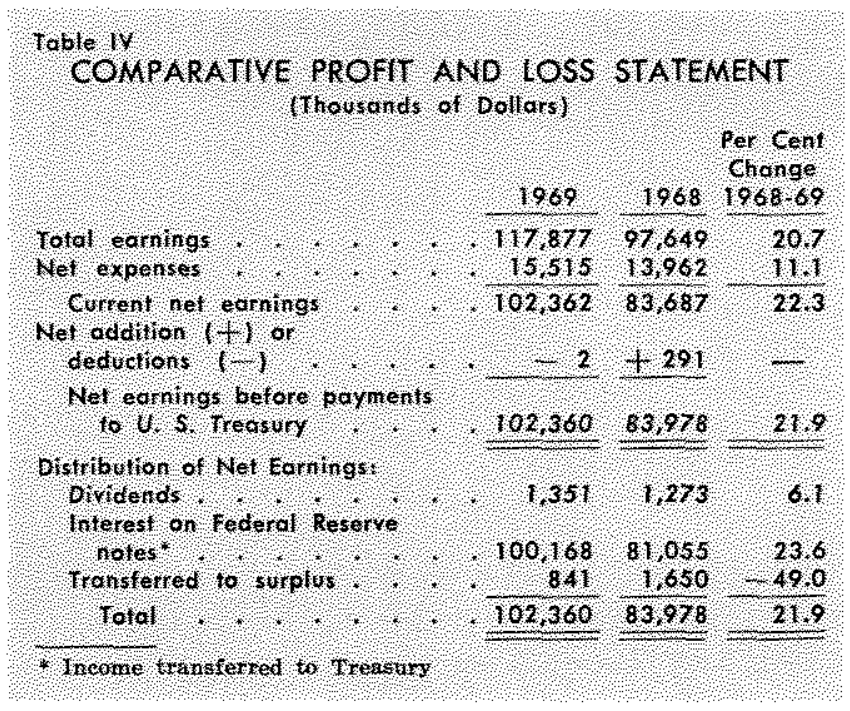

Committee's agent. Although the securities remain at the New York Bank, each Reserve Bank participates in the holdings and earnings of the System Account.

Net earnings before payments to the United States Treasury increased to $\$ 102$ million in 1969 , up 22 per cent from a year earlier. This sharp rise in earnings was due to larger holdings of loans and securities, as well as higher interest rates on these assets, while expenses increased only moderately. After dividends to member banks and increases in surplus, the remaining portion of net earnings are transferred to the U. S. Treasury as interest on Federal Reserve notes. Such transfers totaled $\$ 100$ million in 1969 , up 24 per cent from a year earlier. 